\title{
Do affluent urban consumers drive direct food sales in the N ortheast United States? A three-part analysis
}

\author{
Amy Guptill a * \\ The College at Brockport, SUNY \\ David A. Larsen ${ }^{b}$ and Rick Welsh ${ }^{c}$ \\ Syracuse University \\ Erin Kelly d \\ Utica College
}

Submitted December 13, 2017/ Revised February 14, March 8, March 9, and March 15, 2018 /

Accepted March 17, 2018 / Published online May 8, 2018

Citation: Guptill, A., Larsen, D. A., Welsh, R., \& Kelly, E. (2018). Do affluent urban consumers drive

direct food sales in the Northeast United States? A three-part analysis. Journal of A griculture, Food Systems,

and C ommunity D evelopment, 8(2), 73-86. https://doi.org/10.5304/jafscd.2018.082.005

Copyright (C) 2018 by the Authors. Published by the Lyson Center for Civic Agriculture and Food Systems. Open access under CC BY license.

\begin{abstract}
The last century has seen steady decline in the number of farms and ever-worsening concentration of economic power in the food system. In more recent decades, agricultural sales directly to

a * Corresponding author: Amy Guptill, Department of Sociology, The College at Brockport, SUNY; 350 New Campus Drive; Brockport, NY 14420 USA; +1-585-395-5657; aguptill@,brockport.edu

b David A. Larsen, Department of Public Health, Food Studies and Nutrition, Syracuse University; 344D White Hall; Syracuse, NY 13244 USA; dalarsen@syr.edu

${ }^{\mathrm{c}}$ Rick Welsh, Department of Public Health, Food Studies and Nutrition, Syracuse University; 542 White Hall; Syracuse, NY 13244 USA; jrwelsh@syr.edu

${ }^{\mathrm{d}}$ Erin Kelly, Department of Biology, Utica College; 1600 Burrstone Road; Utica, NY 13502 USA; ekkelly@utica.edu
\end{abstract}

consumers have grown, raising questions about the role of economic privilege and its spatial distribution in supporting direct marketing. We address this question in a three-part analysis of 216 counties in nine Northeast states. First, we compare four direct-sales indicators and their common covariates among county types defined by metropolitan status and adjacency to metro/nonmetro borders. Second, we map four direct-sales variables over these county types. Third, we construct panel regression models with county as a fixed-effect in order to examine the influence of county-level household income on direct agricultural sales while controlling for other county-level variables shown to have an influence: population, vegetable production, farm size, and number of farms. Together, these three perspectives-bivariate, spatial, and multivariate-show that economic privilege is a 
factor in direct food sales, but not necessarily a driver. The variability across the region and the different patterns associated with different directmarketing variables indicate that both researchers and practitioners would benefit from strategies sensitive to context, contingency, and change over time.

\section{Keywonds}

Local Food Systems; Direct Marketing; Spatial Analysis; GIS, Panel Regression

\section{Introduction}

The twentieth and twenty-first centuries have seen a steady decline in the number of U.S. farms as economic power has become more concentrated in all stages of the food system (Constance, Hendrickson, Howard, \& Heffernan, 2014). In 1910, there were more than 6 million farms across the United States, but the 2012 Census of Agriculture counts only about 2 million farms, fewer than half of which sell more than US $\$ 10,000$ in agricultural products per year (U.S. Department of Agriculture National Agricultural Statistics Service [USDA NASS], 2012). Furthermore, the top four percent of farms, with agricultural sales of US $\$ 1$ million or more, account for over two-thirds of all agricultural sales (USDA NASS, 2012). As Constance et al. (2014) note, concentration in agriculture aligns with continuing concentration in the food system as a whole, as fewer and fewer agrifood corporations come to dominate the market both within and across agricultural sectors, a process that has unfolded globally as well as within the U.S. More and more producers find themselves unable to sustain a viable agricultural livelihood at all. As a N ew Y ork Times op-ed highlighted (Smith, 2014), over $90 \%$ of farmers rely on off-farm income (Brown \& Weber, 2013), which is unsurprising as the median farm income recorded in the 2012 census is actually negative: $-\mathrm{US} \$ 1,453$ (USDA Economic Research Service [USDA ERS], 2014).

Among many responses to this deepening crisis is the burgeoning growth of direct agricultural sales through farmers' markets, roadside stands, CSAs, and other direct-to-consumer channels. U.S. direct agricultural sales grew to over US $\$ 1.2$ billion by 2007 (up from US $\$ 404$ million in
1992) and increased another 8 percent between 2007 and 2012 (USDA NASS, 2012). In addition, the USDA reports that the number of farmers' markets nationwide has increased by more than $75 \%$ between 1994 and 2012, with a 9.6\% increase from 2011 to 2012 alone (USDA, 2012), and CSAs are now found on over 12,000 farms nationwide (USDA-NASS, 2012).

Direct-to-consumer marketing cannot, by itself, resolve the ongoing livelihood crisis in American agriculture (Guptill \& Welsh, 2014; Stevenson et al., 2011). It still represents less than 1 percent of all agricultural sales, and the growth of these sales seems to have plateaued (Vogel \& Low, 2015). Locally focused farms are also selling to intermediators, such as stores, restaurants, institutional food services and food hubs; these sales are now more than three times the value of direct-toconsumer agricultural sales (Vogel \& Low, 2015). However, over $85 \%$ of local-food farms (those selling directly to consumers or to intermediaries) sell at least some food direct to consumers, and $70 \%$ sell only to consumers (Vogel \& Low, 2015). Selling direct-to-consumers is an important option for beginning farmers as well as commodityfocused farmers seeking to diversify. Thus it is important to understand what role direct marketing can play in changing the food system.

One central factor shaping the role and relevance of direct marketing is whether it is largely a boutique phenomenon catering to well-off consumers in urban and suburban areas. Research on participation in and practices associated with farmers markets, community supported agriculture operations (CSAs), and other direct-marketing channels shows that they do not escape the troublesome social inequalities in which they are embedded (Alkon \& McCullen, 2010; Lyson, M. C., 2014). While findings about consumers confirm that almost everyone values fresh, healthful food and would like to support local and regional agriculture (Colasanti, Conner, \& Smalley, 2010; Stephenson \& Lev, 2004), not all can play the consumer role in these practices. Spatial inequality influences whether one even has buying opportunities close by (Byker, Shanks, Misyak, \& Serrano, 2012; Colasanti et al., 2010; Stephenson, Lev, \& Brewer, 2008). Also, the physical practices 
of procuring food directly from farms further restricts access to people who have the transportation, time, food budgets, and physical ability needed to participate. Consequently, consumers participating in direct marketing tend to have above-average socio-economic status, including higher levels of formal education: at least, a bachelor's degree (Byker et al., 2012). These consumers also tend to live closer to urban areas than rural regions and to have above-average family incomes (Brown, Gandee, \& D’Souza, 2006; Thilmany, Bond, \& Bond, 2008).

Similarly, not all producers are well placed to incorporate direct marketing or other alternative strategies into their operations (Hardesty \& Leff, 2010; LeRoux, Schmit, Roth, \& Streeter, 2010). Direct agricultural sales tend to be higher in the agriculturally active areas near cities where producers encounter both high land prices — which incentivizes more intensive farming and higher cash gains per acre-and proximate pools of potential customers with higher than average income (Inwood \& Clark, 2013; Lyson, T. A., \& Guptill, 2004; Pfeffer \& Lapping, 1995). Other studies show that direct-selling farms tend to be smaller and sell fruits and vegetables and other high-value crops (Lyson, T. A., \& Guptill, 2004; Monson, Mainville, \& Kuminoff, 2008; Thomas \& Howell, 2003). They are also more likely than other farms to use organic practices and internet marketing (Detre, Mark, Mishra, \& Adhikari, 2011). While most farmers and ranchers value environmental stewardship, social connections, and product quality (Guptill, 2009; Ross, 2006; Selfa \& Qazi, 2005), producers, like consumers, face varying social and economic constraints in pursuing these priorities.

Prior research leads us to a paradox. The values that consumers associate with locally produced foods are widely shared across income categories (Colasanti et al., 2010; Stephenson \& Lev, 2004), but there is a persistent statistical association between economic privilege and participation in direct marketing (Byker et al., 2012). To what extent, then, does economic privilege drive direct agricultural sales? We take a spatial approach to addressing this question by analyzing 216 counties in nine Northeast states:
Connecticut (CT), Maine (ME), Massachusetts (MA), New Hampshire (NH), New Jersey (NJ), New York (NY), Pennsylvania (PA), Rhode Island (RI), and Vermont (VT). The Northeast is the most densely populated region of the U.S., and has the most local food sales (Low et al., 2015). Understanding the dynamics in the Northeast region can help explain the role direct sales can play in promoting positive change in the changing food system, as the rapid growth in direct sales early in the 2000s seems to have plateaued (Vogel \& Low, 2015).

We analyze data from the most recent Censuses of Agriculture and American Community Surveys in three ways. First, we examine four direct-sales indicators and common covariates among counties defined by four types of metropolitan status and adjacency to counties with the opposite metropolitan status. Second, we map four direct-sales indicators over county type. Third, we construct a fixed-time effects regression model in order to examine the influence of consumer household income on direct agricultural sales while controlling for other county-level variables shown to have an influence: population, vegetable production, farm size, and number of farms. Fixed effects (panel data) models examine drivers of change by regressing the difference in the outcome variable across at least two time points on the differences in the predictor variables. In the context of prior research, our place-based analysis would initially suggest that household income is related to direct agricultural sales but is not the sole driver of the phenomenon.

\section{Spatial Patterns of Direct Agricultural Sales}

Most studies of direct agricultural marketing have focused on consumers or farms as the units of analysis (for example, Byker et al., 2012; Colasanti et al., 2010; Inwood \& Clark, 2013; Monson et al., 2008). Studies of consumers show that directmarketing consumers tend to have higher incomes, more years of formal education, and reside closer to or within urban areas (Byker et al., 2012; Thilmany et al., 2008). At the same time, enthusiasm for locally produced foods is widespread among consumers (Colasanti et al., 2010; Stephenson \& Lev, 2004). Farm studies show that 
farm size, crop mix, and other structural variables are associated with the probability of selling agricultural products directly to consumers (Lyson, $\mathrm{T}$. A., \& Guptill, 2004; Monson et al., 2008), as are the backgrounds and motivations of farmers themselves (Inwood \& Clark, 2013; Jarosz, 2011). Income-for both consumers and producersmatters, but it clearly is not the only driving force in direct marketing.

Spatially informed analyses can help to gauge the importance of economic privilege in setting the stage for direct agricultural marketing. As Clark, Inwood, and Sharp (2012) argue, spatial patterns in food systems are dynamic, reflecting both structural factors, like development pressures, as well as the varying values and motivations of producers and consumers in the systems. In one of the first spatial analyses of local and direct food marketing, Brown, Gandee, and D'Souza (2006) constructed a linear regression model of the volume of direct sales (in dollars) in the 55 counties of West Virginia. They found that higher direct sales in 2002 are associated with "higher median housing value, increased population density, a younger population, a greater number of direct market farms, more diversity of fruit and vegetable production and closer proximity to Washington, DC" (Brown et al., 2006, p. 575). In contrast to consumer-level studies, their analysis indicated that counties with a higher percentage of the population holding bachelor's degrees had lower dollar-values of direct sales, suggesting that counties with high direct sales might be selling to out-of-county consumers. They also note that previous studies had "mostly studied urban markets, and those findings may not be applicable to rural areas where residents with lower education levels may have a relatively higher demand for locally grown produce" (Brown et al., 2006, p. 580).

Subsequently, two analyses using 2007 Census of Agriculture data provide additional insights. Timmons and Wang (2010) analyzed state- and county-level data from across the U.S. To account for the vast differences in county size, they used as their dependent variable the natural logarithm of the dollar value of sales per square mile. Like Brown et al. (2006), their independent variables included population density, percentage of land in farming, and an indicator of vegetable production. In contrast to Brown et al. (2006), they measured socio-economic status with median household income, rather than housing values and education, and they did not include age structure, proximity to metropolitan areas, or indicators of farm-level direct sales. Altogether, Timmons and Wang (2010) found that five variables - farm size, population density, percentage of land in farming, percentage of farms growing vegetables, and median income-along with region, accounted for 64 percent of the county-level variance in direct marketing.

Cheng, Bills, and Uva (2011) performed an analysis similar to Timmons and Wang but focused on eleven Northeast states, the same nine that we use (CT, ME, MA, NH, NJ, NY, PA, RI, and VT) as well as Delaware and Maryland. They used the same dependent variable as Timmons and Wangthe natural $\log$ of the dollar value of direct sales per square mile-and some of the same independent variables: average farm size, percentage of land in farming, percentage of farms growing vegetables, and median household income. They also included population (rather than population density), percentage of farms raising cattle, percentage of farms growing fruit, county metropolitan status, and three indicators of marketing channels present in the county: number of farmers markets per 1000 population, ratio of farms marketing through CSAs, and the presence or absence of a farm-toschool program. With the exception of fruit production and metropolitan status, all of the variables were significant with coefficients in the predicted directions.

More recently, O'Hara and Low (2016) have analyzed changing direct sales on a county level between 1992 and 2012, and find that increasing per capita incomes in metropolitan areas within 100 or 150 miles of a county is associated with a striking increase in the county's direct-to-consumer sales. That is, an increase in per capita income of US\$1000 in a metropolitan statistical area is associated with a US $\$ 70,900$ increase in the annual direct sales of counties within 100 miles $(161 \mathrm{~km})$ and a US\$57,200 increase in direct sales in counties within 150 miles $(241 \mathrm{~km})$. They control for changes in demographics in nearby metropolitan 
statistical areas (MSAs): total MSA population, percent population Hispanic and non-Hispanic white, and percentage of population in three adult age groups. They also control for metropolitan status and adjacency to metropolitan areas. They calculated a model using local county-level socioeconomic and demographic variables, eliminating those counties, generally in the largest cities, that do not report direct-to-consumer sales. An incounty increase in per capita income of US $\$ 1,000$ was associated with an increase in direct sales of US $\$ 38,600$. Population growth within a county had a positive effect on direct sales, but population growth in nearby MSAs did not. They conclude that demand for direct-to-consumer agricultural products has a high income elasticity.

We see a need for further study in this area for two reasons. First, while dollar value of direct sales, either absolute or per square mile, is a meaningful outcome, it is also important to explore how explanatory variables might change with other measures of direct marketing activity. If direct agricultural sales are framed solely as economic activities, then economic volume is the most important outcome variable. However, if one views direct sales as part of a broader food movement, as we do, then the numbers and proportions of farms participating, as well as the proportion of agricultural sales that are direct-to-consumer are also important. A second contribution we make is to examine these questions with a fixed-time effects model that can account for hidden time-invariant spatial variables. O'Hara and Low (2015) demonstrate the importance of market areas beyond county boundaries and change over time, but they also exclude from their analysis counties whose population centroid are not within 100 miles (in one model) or 150 miles (in the other model) of the population centroid of an MSA. Our study also accounts for change over time, but in a way that includes even the most rural counties in the region as well as supply-side factors shown to make a difference in prior studies (Brown et al., 2006; Cheng et al., 2011; Timmons \& Wang, 2010).

\section{Data and Methods}

From the 2007 and 2012 Censuses of Agriculture we draw four outcome variables: the number of direct-selling farms, the percentage of farms selling directly to consumers, the total dollar value of direct sales, and the percentage of all agricultural sales that are direct to consumer. For the USDA National Agricultural Statistics Service, direct sales are defined as "products that were sold directly to individual consumers for human consumption" (USDA NASS, 2012, p. 54). Sales directly to restaurants or retailers are instead called intermediate sales; the 2012 Census of Agriculture measured them for the first time. In addition to the outcome variables, we also draw from the Census of Agriculture independent variables for the number of farms, land area, median farm size and acres of vegetable production, all shown in prior research to be predictors of direct sales. The county is our unit of analysis, and we include the 216 counties in nine Northeast U.S. states (CT, ME, MA, NH, NJ, NY, PA, RI, VT).

In addition to the four outcome variables, we draw four agricultural control variables from the 2007 and 2012 censuses: number of farms, median farm size, number of farms producing vegetables, and acres in vegetable production. We also gather the five-year estimates of median household income (our independent variable) and population (a control variable) from the American Community Survey for 2009 and 2012; 2009 is the closest year to 2007 in which these data are available for all counties in the Northeast. These control variables were included in prior studies and reflect recent findings about direct sales (Cheng et al., 2011; Timmons \& Wang, 2010).

For the bivariate analysis and spatial visualization, we constructed a metropolitan adjacency variable drawing on metropolitan status as defined by the Office of Management and Budget in 2013. Metropolitan counties are those that include urbanized areas with a population of 50,000 or more as well as the outlying counties from which 25 percent or more of workers commute. Any other counties are considered non-metropolitan. With that definition and the tools of ArcGIS, we created a metropolitan-adjacency variable with four categories: (1) nonmetropolitan counties not adjacent to any metropolitan county, (2) nonmetropolitan county adjacent to at least one metropolitan county, (3) metropolitan county adjacent to at least one 
nonmetropolitan county, (4) metropolitan county not adjacent to any nonmetropolitan counties.

Table 1 shows basic descriptive statistics for all variables included in the analyses for both 20072009 and 2012 values. It shows that while direct sales have plateaued nationally the means of all four indicators of direct marketing have grown between 2007 and 2012 in the Northeast: the number and percentage of farms selling direct, the dollar value of direct sales, and the percentage of sales that are direct. Median household income and population have also increased, while the mean number of farms, median farm size, number of vegetable farms and acres in vegetables have fallen.

We conducted a three-part analysis. First, we examined bivariate patterns by metropolitan adjacency (Table 2); second, we mapped outcome variables by metropolitan adjacency to visualize spatial patterns. Third, to clarify the impacts of income, we entered these variables into panel regression models with county as a fixed effect (one for each of the four outcome variables) as demonstrated by the following equation:

$$
Y_{i t}=\beta X_{i t}+\alpha_{i}+\varepsilon_{i t}
$$

This approach regresses the change in the outcome variable $\left(\mathrm{Y}_{\mathrm{it}}\right)$ from time 1 (2007) to time 2 (2012) on the change in predictor variables $\left(\beta \mathrm{X}_{\mathrm{it}}\right)$ over the same time period after accounting for unchanging characteristics of each county $\left(\alpha_{i}\right)$, which are the fixed panel effects. One significant advantage of a fixed-effects panel model is that it accounts for any confounding variables that are constants through time, such as proximity to major population centers and transportation corridors (Brown et al., 2006; O’Hara \& Low, 2016). Thus, our metropolitan adjacency variable is not included in the fixed-effects model, as it does not vary between time 1 and time 2 .

Table 1. Descriptive Statistics

\begin{tabular}{|c|c|c|c|c|c|c|}
\hline \multirow[b]{2}{*}{ Variable } & \multirow[b]{2}{*}{ Source } & \multicolumn{2}{|c|}{$2007 / 2009$} & \multicolumn{2}{|c|}{2012} & \multirow{2}{*}{$\begin{array}{c}\text { Difference } \\
\text { in means } \\
\text { 2012-2007 }\end{array}$} \\
\hline & & Mean & $\begin{array}{l}\text { Standard } \\
\text { deviation }\end{array}$ & Mean & $\begin{array}{l}\text { Standard } \\
\text { deviation }\end{array}$ & \\
\hline \multicolumn{7}{|l|}{ DEPENDENT VARIABLES } \\
\hline $\begin{array}{l}\text { Number of farms selling } \\
\text { direct }\end{array}$ & USDA-NASS Census of Agriculture & 103.2 & 76.1 & 119.4 & 85.1 & 16.2 \\
\hline $\begin{array}{l}\text { Percent of farms selling } \\
\text { direct }\end{array}$ & USDA-NASS Census of Agriculture & $17.5 \%$ & $8.6 \%$ & $21.0 \%$ & $9.3 \%$ & $3.5 \%$ \\
\hline $\begin{array}{l}\text { Direct sales (US } \$ 1,000 \\
\text { current dollars) }\end{array}$ & USDA-NASS Census of Agriculture & $\$ 1,547$ & $\$ 1,634$ & $\$ 1,804$ & $\$ 1,811$ & $\$ 257$ \\
\hline Percentage of sales direct & USDA-NASS Census of Agriculture & $4.29 \%$ & $4.56 \%$ & $5.36 \%$ & $6.49 \%$ & $1.07 \%$ \\
\hline \multicolumn{7}{|l|}{ INDEPENDENT VARIABLE } \\
\hline $\begin{array}{l}\text { Median household income } \\
\text { (US\$) }\end{array}$ & ACS, 5-year estimates & $\$ 52,840$ & $\$ 13,957$ & $\$ 55,140$ & $\$ 13,858$ & $\$ 2,300$ \\
\hline \multicolumn{7}{|l|}{ CONTROL VARIABLES } \\
\hline Population & ACS, 5-year estimates & 248,401 & 102,100 & 250,697 & 102,200 & 2,296 \\
\hline Total number of farms & USDA-NASS Census of Agriculture & 665 & 539 & 646 & 531 & -19 \\
\hline Median farm size (acres) & USDA-NASS Census of Agriculture & 62 & 39 & 63 & 37 & 1 \\
\hline $\begin{array}{l}\text { Number of farms producing } \\
\text { vegetables }\end{array}$ & USDA-NASS Census of Agriculture & 65 & 69 & 59 & 61 & -6 \\
\hline $\begin{array}{l}\text { Acres in vegetable } \\
\text { production }\end{array}$ & USDA-NASS Census of Agriculture & 1,720 & 4,887 & 1,594 & 4,942 & -126 \\
\hline
\end{tabular}

Note: 1 acre $=0.4$ hectare 


\section{Results}

\section{Bivariate Results}

Table 2 compares the means of variables in the model by metropolitan-adjacency category: nonmetro, nonborder; nonmetro, border; metro, border; metro, nonborder. The table shows that metropolitan-adjacent counties-either metropolitan or nonmetropolitan-have more farms selling direct than nonmetropolitan-adjacent counties (116 and 137 versus 93 and 103). However, metropolitan-adjacent counties have smaller proportions of farms selling direct (roughly one in five versus one in four) and smaller percentages of sales that are direct than non-adjacent counties ( 4 and 5 percent versus about 7.5 percent). The mean dollar value of direct sales, in contrast, rises from the most rural counties to the most urban ones: US $\$ 917,000$ per year in nonmetropolitan, nonmetropolitan-adjacent counties, to US $\$ 2,432,000$ in metropolitan, nonmetropolitan-adjacent counties, a 2.6-fold increase. Household income and population both, predictably, also increase from more rural counties to more urban ones. Metropolitan-adjacent counties, both metropolitan and nonmetropolitan, have more farms than nonmetropolitan-adjacent counties, while nonmetropolitan counties tend to have larger farms and fewer farms producing vegetables. Mean acres in vegetables is largest in nonmetropolitan counties adjacent to metropolitan ones, but it only slightly exceeds that of metropolitan, nonmetropolitan-adjacent counties.

Overall, these bivariate results indicate that the narrative of urban-fringe locations being prime opportunities for direct sales is somewhat oversimplified. Rural-urban adjacent counties have higher absolute numbers of direct-selling farms, but the largest volume of direct agricultural sales are among farms in metropolitan counties (metropolitan-adjacent or not). With slightly higher median incomes and much higher populations, it is clear why absolute values would be higher in metropolitan counties. On the other hand, the relative measures - the percentage of farms selling direct and percentage of sales that are direct—are notably higher in nonmetropolitan-adjacent counties (both nonmetropolitan and metropolitan). Contrary to common assumptions, direct sales are smaller parts of the agricultural economies of adjacent rural-urban counties.

Table 2. Means by Metropolitan-Adjacency Category

\begin{tabular}{|c|c|c|c|c|c|}
\hline Variable & $\begin{array}{l}\text { Nonmetro, } \\
\text { nonborder }\end{array}$ & $\begin{array}{c}\text { Nonmetro, } \\
\text { border }\end{array}$ & Metro, border & $\begin{array}{c}\text { Metro, } \\
\text { nonborder }\end{array}$ & Overall \\
\hline & $\mathrm{n}=14$ & $\mathrm{n}=80$ & $\mathrm{n}=78$ & $\mathrm{n}=44$ & $\mathrm{~N}=216$ \\
\hline \multicolumn{6}{|l|}{ DEPENDENT VARIABLES } \\
\hline Number of farms selling direct & 93 & 116 & 137 & 103 & 119 \\
\hline Percent of farms selling direct & $24.5 \%$ & $19.3 \%$ & $19.7 \%$ & $23.8 \%$ & $20.7 \%$ \\
\hline Direct sales (US\$1,000 current dollars) & $\$ 917$ & $\$ 1,241$ & $\$ 2,221$ & $\$ 2,432$ & $\$ 1,804$ \\
\hline Percentage of sales direct & $7.5 \%$ & $4.0 \%$ & $4.9 \%$ & $7.4 \%$ & $5.4 \%$ \\
\hline \multicolumn{6}{|l|}{ INDEPENDENT VARIABLE } \\
\hline Median household income (US\$) & $\$ 44,983$ & $\$ 47,832$ & $\$ 55,738$ & $\$ 69,621$ & $\$ 55,140$ \\
\hline \multicolumn{6}{|l|}{ CONTROL VARIABLES } \\
\hline Population & 33,752 & 61,536 & 242,021 & 679,033 & 250,697 \\
\hline Total number of farms & 398 & 657 & 721 & 538 & 646 \\
\hline Median farm size in acres & 79 & 84 & 59 & 20 & 63 \\
\hline Number of farms producing vegetables & 43 & 56 & 74 & 74 & 59 \\
\hline Acres in vegetable production & 263 & 1,828 & 1,475 & 1,804 & 1,594 \\
\hline
\end{tabular}

Note: 1 acre $=0.4$ hectare 
Spatial V isualization

Figures 1 through 4 overlay the four outcome variables on the metropolitan adjacency categories shown in Table 2. Figure 1 shows that direct-selling farms are found in almost all counties, regardless of their metropolitan status or adjacency to the metro/nonmetro border. Some concentration of farms around major metropolitan areas is visible, and Vermont stands out as home to many direct-selling farms. Figure 2 shows that the highest percentages of farms selling direct to consumers are not necessarily proximate to all major metropolitan areas, but are, rather, found primarily in northern New England and central Massachusetts. Figure 3 also illustrates the pattern shown in Table 2 , that metropolitan counties, bordering or not, see the highest volume of direct agricultural sales. Vermont, again, stands out with a noticeable concentration of sales. Figure 4 shows that the highest percentages of direct-toconsumer sales are not in the same array of counties with the highest percentages of direct-selling farms. Fewer northern New England counties
Figure 1. Number of Direct-selling Farms and Metropolitan Adjacency

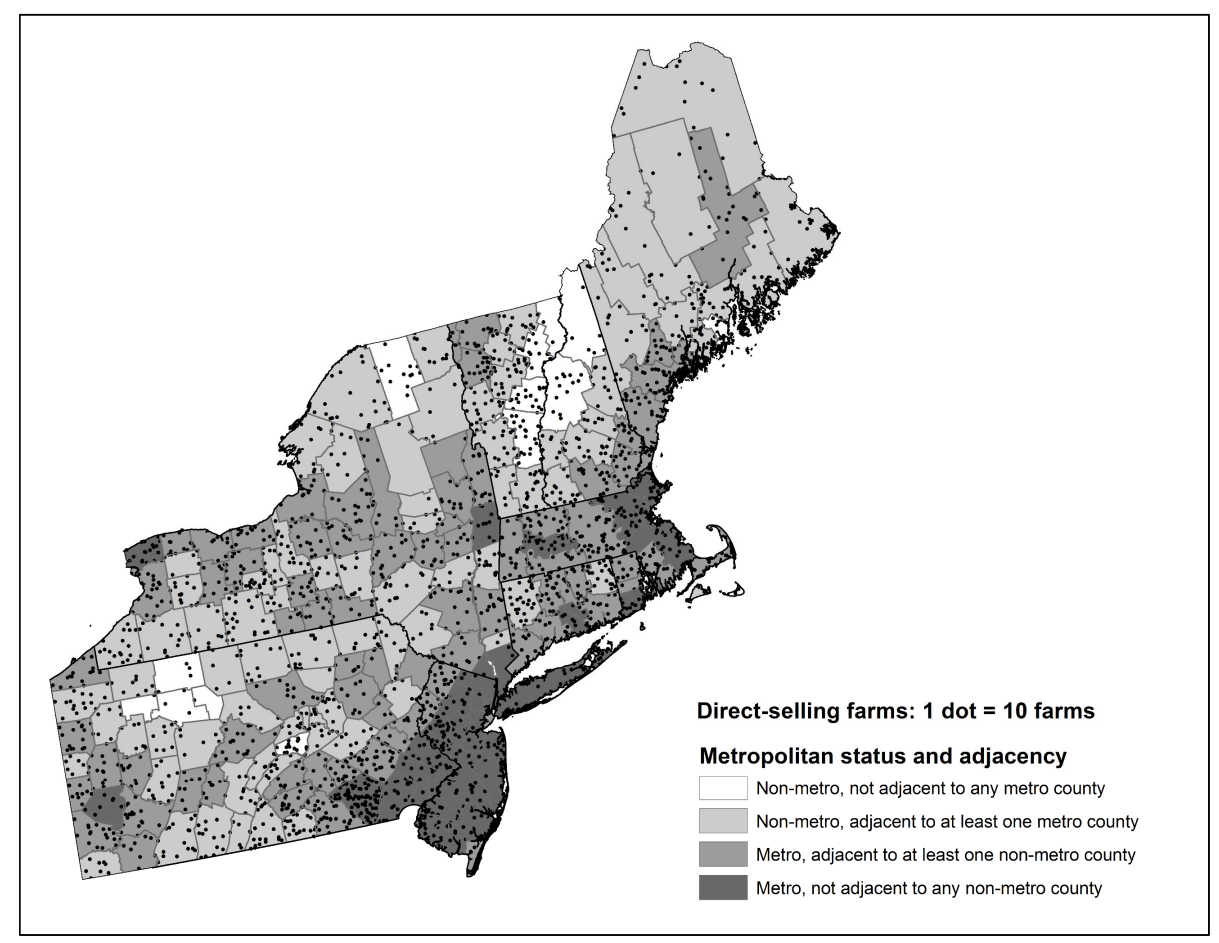

Figure 2. Top-quartile of Percent of Farms Selling Direct and Metropolitan Adjacency

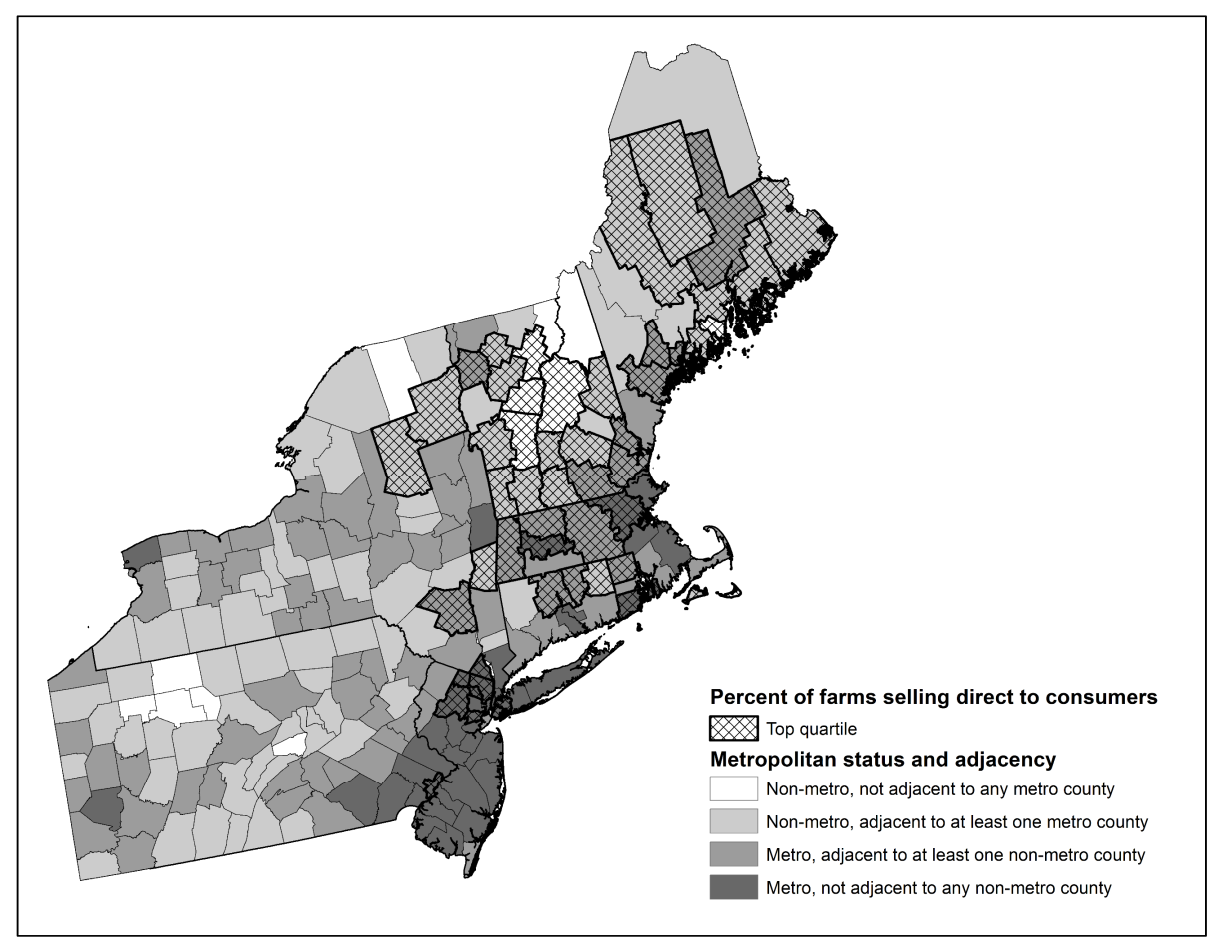


Figure 3. Volume of Direct Sales and Metropolitan Adjacency

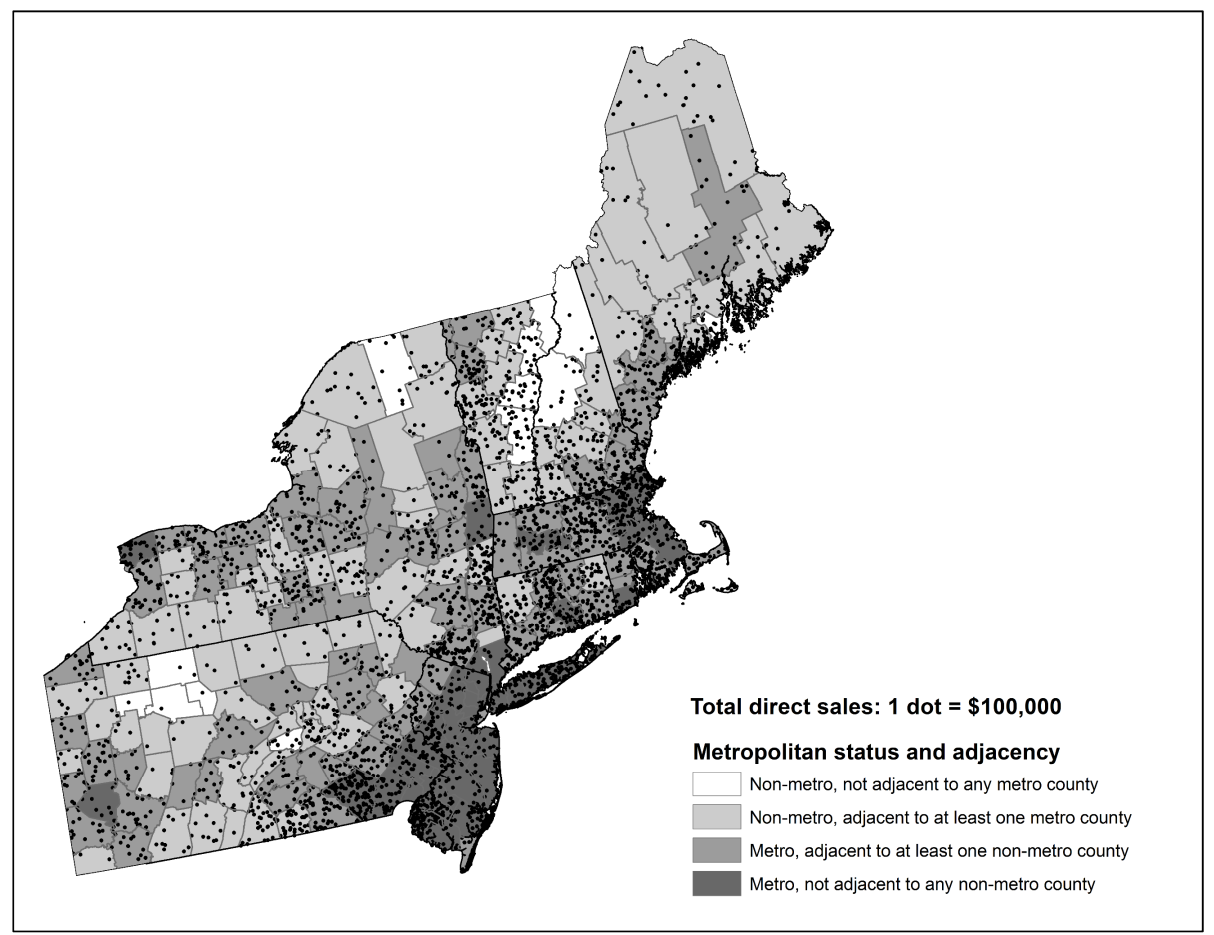

Figure 4. Top-quartile of Percent of Sales Direct to Consumer and Metropolitan Adjacency

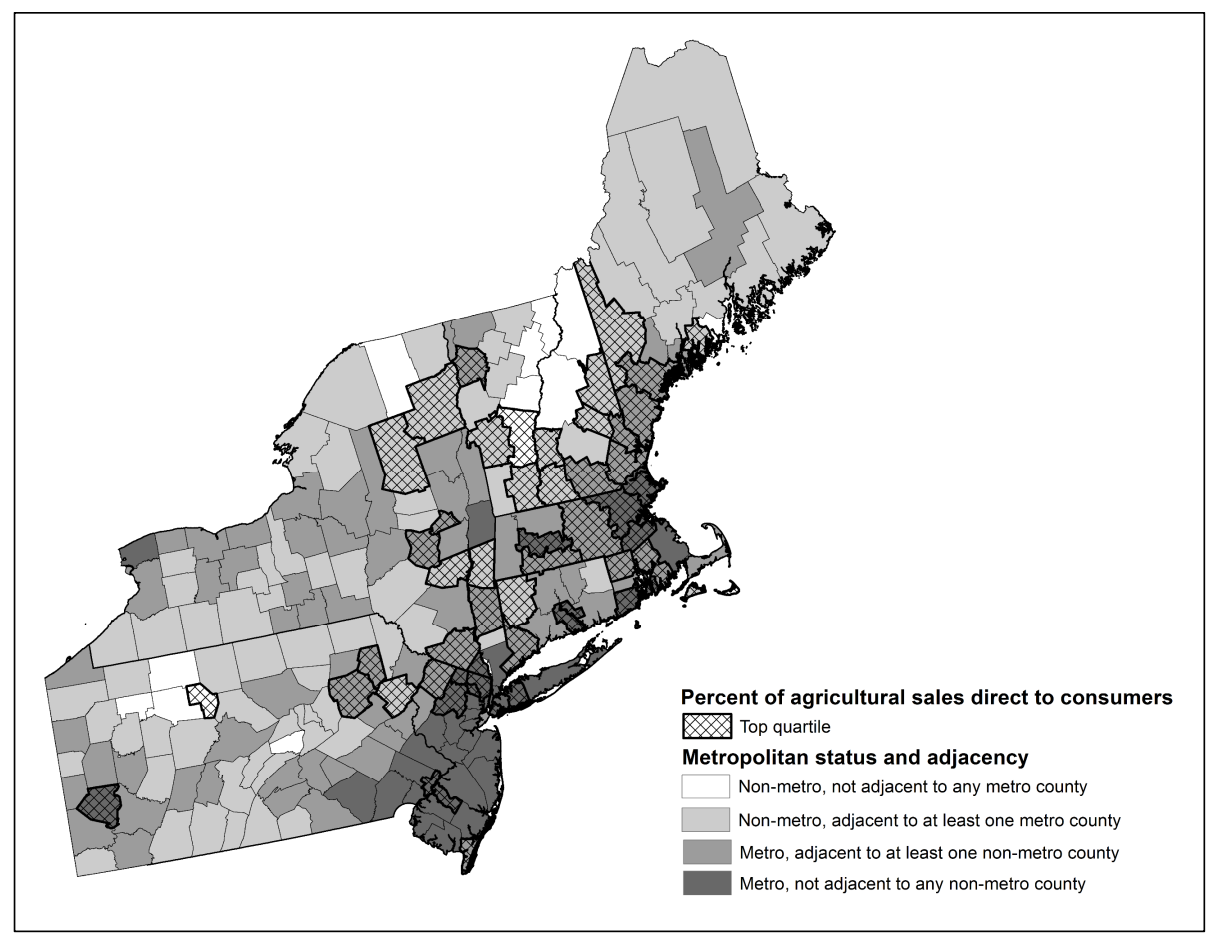

are in the top quartile. Instead, the highest proportions of direct sales seem to occur in counties along interstate routes to Boston and New York City.

Together, the descriptive statistics and spatial visualizations show complex patterns, not necessarily driven by household income.

Notably, the patterns change depending on how direct marketing is measured. To examine these patterns in a multivariate context, we entered our data into a series of fixed-time effect regression models.

\section{Fix ed-time E ffect} Regression Results

Table 3 summarizes standardized fixed-time effect regression results to isolate how changes in median household income and each control variable are associated with changes in the direct-sales variables between 2007 and 2014 . Controlling for other variables, the change in the number of farms (Model 1) selling direct between 2007 and 2012 can be partly explained by most variables in the model. Increase in household income has a positive relationship to growth in number of farms selling direct, as does the total number of 
farms, growing median farm size, and growing number of farms producing vegetables. Increasing population has a significant negative relationship to the number of farms selling direct, and acres in vegetables is negatively related to the number of direct-selling farms, though the effect is not significant. The overall $\mathrm{R}^{2}$ for the model is 0.48 .

Interestingly, household income is not a significant predictor for growth in the percentage of farms selling direct (Model 2). Population and the number of vegetable farms are positively related to percentage of farms selling direct, while the total number of farms and acres in vegetables are negatively related. Median farm size is unrelated. It is a slightly less powerful model, with an overall $\mathrm{R}^{2}$ of 0.41 . The beta coefficients for volume of direct sales (Model 3) shows yet another pattern, with income and number of vegetable farms significant and positive in the model, while the total number of farms is significant and negative. This is the least predictive model of the four, with an overall $\mathrm{R}^{2}$ of 0.37 . Finally, changes in the percentage of direct-to-consumer sales (Model 4) are also distinct, with the number of vegetable farms positively related and the total number of farms, median farm size, and acres in vegetables negatively related to direct sales. Income and population are unrelated. The overall $\mathrm{R}^{2}$ for Model 4 is 0.44 .
To summarize the role of income, it seems to have a positive relationship to the number of farms selling direct (Model 1) and the volume of direct sales (Model 3), but is unrelated to the percentage of farms selling direct (Model 2) and the percentage of direct sales (Model 4). Population, in contrast, is negatively related to the number of farms selling direct (Model 1), positively related to the percentage of farms selling direct (Model 2), but unrelated to the volume of direct sales (Model 3) or the percentage of sales that are direct (Model 4).

Direct agricultural sales appear to be more complex in the Northeast than simply a high-income, periurban phenomenon.

\section{Implications}

Examining the role of household income and metropolitan adjacency in promoting direct agricultural marketing from three perspectivesbivariate, spatial, and multivariate-reveals that income and location in terms of metropolitan areas matter to some measures of direct sales. It is inaccurate, however, to dismiss direct marketing as a boutique phenomenon catering to privileged consumers in the suburbs. The strength and the direction of the statistical link between income and direct marketing varies by whether one uses an absolute (farms, sales volume) or relative

Table 3. Fixed-effects Results

\begin{tabular}{|c|c|c|c|c|c|c|c|c|}
\hline & \multicolumn{2}{|c|}{$\begin{array}{l}\text { Model } 1 \\
\text { Number of farms } \\
\text { selling direct }\end{array}$} & \multicolumn{2}{|c|}{$\begin{array}{c}\text { Model } 2 \\
\text { Percentage of farms } \\
\text { selling direct }\end{array}$} & \multicolumn{2}{|c|}{$\begin{array}{c}\text { Model } 3 \\
\text { Direct sales (US\$1,000 } \\
\text { current dollars) }\end{array}$} & \multicolumn{2}{|c|}{$\begin{array}{c}\text { Model } 4 \\
\text { Percentage of } \\
\text { direct sales }\end{array}$} \\
\hline & Beta & $\begin{array}{c}\text { Standard } \\
\text { error }\end{array}$ & Beta & $\begin{array}{l}\text { Standard } \\
\text { error }\end{array}$ & Beta & $\begin{array}{c}\text { Standard } \\
\text { error }\end{array}$ & Beta & $\begin{array}{c}\text { Standard } \\
\text { error } \\
\end{array}$ \\
\hline Household income & $0.26 * * *$ & 0.05 & 0.10 & 0.06 & $0.44 * * *$ & 0.07 & 0.15 & 0.06 \\
\hline Population & $-0.35 * * *$ & 0.05 & $0.13 * *$ & 0.06 & 0.12 & 0.07 & 0.06 & 0.07 \\
\hline Total farms & $0.34 * * *$ & 0.07 & $-0.96 * * *$ & 0.08 & $-0.29 * * *$ & 0.09 & $-0.55 * * *$ & 0.08 \\
\hline Median farm size & $0.14 * *$ & 0.05 & 0.04 & 0.07 & -0.01 & 0.07 & $-0.21 * * *$ & 0.07 \\
\hline Vegetable farms & $0.33 * * *$ & 0.06 & $0.83 * * *$ & 0.08 & $0.23 * *$ & 0.08 & $0.35 * * *$ & 0.07 \\
\hline Acres in vegetables & -0.03 & 0.05 & $-0.23 * * *$ & 0.05 & 0.06 & 0.06 & $-0.18 * * *$ & 0.05 \\
\hline $\mathrm{R}^{2}$ within & .25 & & .21 & & .00 & & .01 & \\
\hline$R^{2}$ between & .51 & & .45 & & .40 & & .46 & \\
\hline $\mathrm{R}^{2}$ overall & .48 & & .41 & & .37 & & .44 & \\
\hline
\end{tabular}

$* \mathrm{p}<0.01 ; * * \mathrm{p}<0.005, * * * \mathrm{p}<0.001$ 
(percentage of farms, percentage of sales) outcome measure. O'Hara and Low (2016) usefully demonstrate the income elasticity of demand for directmarketed agricultural products, but our study, and others, emphasize contributions of other factors that can lead to a positive change in the structure of the food system: wealth of farm resources, types of agricultural products, and spatial considerations such as proximity to major cities and transportation corridors (Brown et al., 2006; Cheng et al., 2011; Clark, Inwood, \& Sharp, 2012; Selfa \& Qazi, 2005).

Understanding affluence as a factor in (but not a driver of) direct agricultural sales is important for at least two reasons:

1. Most analyses treat the Northeast U.S. as one relatively homogenous region, characterized by dense settlement patterns and relative social privilege, when considering direct marketing in agriculture (e.g., Lyson, T. A., 2004; Timmons \& Wang, 2010). Our analyses, however, show considerable variation in socioeconomic and ecological contexts within the Northeast. This variation is important for food system work, as each locale is best understood as a unique configuration of broader spatial and economic patterns.

2. The increase in direct markets is often attributed to the presence of higher-income people living in urban and peri-urban areas. Although there is significant association between direct-sales outcomes and access to high-income markets, our models indicate that the total picture is more complex. Therefore, specific strategies to promote direct markets for areas with more modest incomes and less dense populations could prove fruitful. For example, regional foodsystem efforts might be more effective than local ones in serving less privileged places (Brekken, Parks, \& Lundgren, 2017)

Direct marketing can take a variety of forms, which have discrete drivers depending on the context. Therefore, policy aimed at promoting or enabling shorter supply chains and direct markets should take this heterogeneity into account.

We also note that the visually striking way that Vermont stands out also indicates that current levels of direct marketing are not circumscribed by household income. The regression model constructed by Timmons and Wang (2010) predicted direct sales for Vermont of US\$10.5 million when the observed volume of direct sales in the 2007 Census of Agriculture was over twice that at US $\$ 22.9$ million. Conner, Dewitt, Inwood, and Archer (2015) highlight the role of Vermont's 2009 "Farm to Plate" legislation, which created a 10-year plan for promoting economic development, employment, and public health through a more sustainable food system. This statewide commitment supports the efforts of socially responsible food and agricultural businesses in the state and has yielded growth in both the number of food businesses and the number of jobs in the food sector. It is unlikely that another state or region can walk exactly in Vermont's footsteps, given the state's compelling brand in the minds of many consumers, ${ }^{1}$ but in the broader context of our analysis, the Vermont case illustrates the rich possibilities of strategic food systems work and policy advocacy.

\section{Conclusions}

Our research reinforces the notion that researchers and policy-makers interested in direct marketing activities in agriculture should view local food systems as potentially complex phenomena nested in broader contexts. In-depth case studies together with broader quantitative analyses can better explicate the ideal types of direct markets we have measured here. In this way, we can avoid idealizing or dismissing direct food markets as panaceas or as irrelevant, respectively, for rural development when not appropriate. While our work reveals some insights about the limited and contextual role of economic privilege in direct food marketing, it has several notable limits.

First, direct-to-consumer sales are only part of the local food picture. Future analyses of the role

\footnotetext{
${ }^{1}$ We are indebted to an anonymous reviewer for this point.
} 
of economic privilege in facilitating local food systems will likely focus on newer data on intermediate marketing channels. The 2012 Census of Agriculture for the first time collected data on farm sales direct to retailers (restaurants, stores, institutional kitchens) and aggregators serving local markets (food hubs and local distributors). Intermediated sales in 2012, at US $\$ 4.8$ billion, are more than three times the volume of direct-to-consumer sales (Vogel \& Low, 2015); the sharply reduced growth of direct-to-consumer sales between 2007 and 2012 may be explained by these expanded marketing opportunities for locally focused farmers. Also, intermediated sales may be more profitable avenues for some farms (Uematsu \& Mishra, 2011). Direct-to-consumer and intermediated sales are two interacting parts of a broader local food system. While our data are only a few years old, the emergence of food hubs and other locally and regionally focused efforts may make our findings quickly out-of-date.

Second, while our fixed-effects model demonstrates the usefulness of considering change over time, it does not, by itself, provide a rich narrative of how change is created at the local and regional levels. For example, Hoey, Colasanti, Pirog, and Fink Shapiro (2017), reflecting on food-system work in Michigan, emphasize the critical importance of trust among social-change stakeholders to create processes that can lead to effective change in policies and practices. Similarly, Godette, Beratan, and Nowell (2015) show that uniform strategies for local food system development are often poorly aligned with contingent local conditions, such as the attitudes and policies of institutional food buyers. Trust, relationships, attitudes, and even policies are dimensions of food-system contexts that are invisible to the Census of Agriculture.

Third, our model is limited by data availability. It is based on 2007 and 2012 data from the Census of Agriculture and corresponding years of the American Community Survey. While the agricultural data are the most recent available, they are still somewhat out of date. Similarly, with $\mathrm{R}^{2}$ values ranging from 0.37 to 0.48 , more than half the variance in direct sales is due to unexplained factors. While the fixed-effects panel model accounts for variables that are constant through time (such as proximity to major urban areas), there are clearly other variables that changed between 2007 and 2012 that help shape direct sales outcomes.

As researchers pursue varied projects emphasizing diverse dimensions of the food system, our results suggest that future analyses would be enriched in two ways. First, including multiple measures of local-food activity enables research to capture both economic flows and promising structural change. Second, modeling techniques like fixed-time effects regression are effective in accounting for unmeasured time-constant variables and, in that way, representing some of the subtle complexities of broad food-system change.

\section{Acknowledgements}

Our thanks to three anonymous JAFSCD review-

ers for their many helpful comments on this article.

\section{References}

Alkon, A. H., \& McCullen, C. G. (2010). Whiteness and farmers markets: Performances, perpetuations ... contestations? A ntipode, 43(4), 937-959. https://doi.org/10.1111/j.1467-8330.2010.00818.x

Brekken, C. A., Parks, M., \& Lundgren, M. (2017). Oregon producer and consumer engagement in regional food networks: Motivations and future opportunities. Journal of A griculture, F ood Systems, and C ommunity D evelopment, 7(4), 79-103. https://doi.org/10.5304/jafscd.2017.074.008

Brown, C., Gandee, J. E., \& D’Souza, G. (2006). West Virginia farm direct marketing: A county level analysis. Journal of A griculture and A pplied E conomics, 38(3), 575-584. https://doi.org/10.1017/S1074070800022628

Brown, J. P., \& Weber, J. G. (2013). The off-farm occupations of U .S. farm operators and their spouses (EIB-117). Washington, D.C.: U.S. Department of Agriculture, Economic Research Service. Retrieved from https://www.ers.usda.gov/webdocs/publications/43789/40009_eib-117.pdf

Byker, C., Shanks, J., Misyak, S., \& Serrano, E. (2012). Characterizing farmers' market shoppers: A literature review. Journal of H unger and E nvironmental N utrition, 7(1), 38-52. https://doi.org/10.1080/19320248.2012.650074 
Cheng, M.-I., Bills, N., \& Uva, W.-F. L. (2011). Farm-direct food sales in the Northeast region: A county-level analysis. Journal of Food D istribution Research, 42 (1), 22-25. http://purl.umn.edu/139273

Clark, J. K., Inwood, S., \& Sharp, J. S. (2012). Local food systems: The birth of new farmers and the demise of the family farm? In J. Gatrell, P. S. Ross, \& N. Reid (Eds.), L ocal food systems in old industrial regions: Concepts, spatial ontext, and local practices (pp. 131-145). Abingdon, Oxon, UK: Ashgate.

Colasanti, J. A., Conner, D. S., \& Smalley, S. B. (2010). Understanding barriers to farmers' market patronage in Michigan: Perspectives from marginalized populations. Journal of H unger and E nvironmental N utrition, 5(3), 313-338. https://doi.org/10.1080/19320248.2010.504097

Conner, D. S., Dewitt, R., Inwood, S. M., \& Archer, M. (2015). Social responsibility and community development in Vermont's food business. Journal of Food Research, 4(6), 93-103. https://doi.org/10.5539/jfr.v4n6p93

Constance, D., Hendrickson, M., Howard, P., \& Heffernan, W. D. (2014). Economic concentration in the food system: Impacts on rural communities and emerging responses. In C. Bailey, L. Jensen, and E. Ransom (Eds.), Rural A merica in a globalizing world (pp. 16-35). Morgantown: West Virginia University Press.

Detre, J. D., Mark, T. B., Mishra, A. K., \& Adhikari, A. (2011). Linkage between direct marketing and farm income: A double-hurdle approach. A gribusiness, 27(1), 19-33. https://doi.org/10.1002/agr.20248

Godette, S. K., Beratan, K., \& Nowell, B. (2015). Barriers and facilitators to local food market development: A contingency perspective. Journal of A grialture, F ood Systems, and C ommunity D evelopment, 5(3), 79-96. https://doi.org/10.5304/jafscd.2015.053.012

Guptill, A. (2009). Exploring the conventionalization of organic dairy: Trends and counter-trends in Upstate New York. A griculture and H uman V alues, 26(1), 29-42. https://doi.org/10.1007/s10460-008-9179-0

Guptill, A., \& Welsh, R. (2014). The declining middle of American agriculture: A spatial phenomenon. In C. Bailey, L. Jensen, \& E. Ransom (Eds.), Rural A merica in a globalizing world (pp. 36-50). Morgantown: West Virginia University Press.

Hardesty, S. D., \& Leff, P. (2009). Determining marketing costs and returns in alternative marketing channels. Renewable A griculture and Food Systems, 25(1), 24-34. https://doi.org/10.1017/S1742170509990196

Hoey, L., Colasanti, K., Pirog, R., \& Fink Shapiro, L. (2017). Implementing collective impact for food systems change: Reflections and adaptations from Michigan. Journal of A griculture, F ood Systems, and Community D evelopment, 7(2), 101115. https://doi.org/10.5304/jafscd.2017.072.014

Inwood, S. M., \& Clark, J. K. (2013). Farm adaptation at the rural-urban interface. Journal of A grialture, F ood Systems, and Community D evelopment, 4(1), 61-78. https://doi.org/10.5304/jafscd.2013.041.007

Jarosz, L. (2011). Nourishing women: Toward a feminist political ecology of community supported agriculture in the United States. G ender, Plaœ, and Culture, 18(3), 307-326. https://doi.org/10.1080/0966369X.2011.565871

LeRoux, M. N., Schmit, T. M., Roth, M., \& Streeter, D. H. (2010). Evaluating marketing channel options for small-scale fruit and vegetable producers. Renewable A griculture and F ood Systems, 25(1), 16-23. https://doi.org/10.1017/S1742170509990275

Low, S. A., Adalja, A., Beaulieu, E., Key, N., Martinez, S., Melton, A. .. Jablonski, B. B. R. (2015). Trends in U .S. local and regional food systems: A report to Congress (AP-068). Washington, D.C.: USDA, Economic Research Service. Retrieved from https://www.ers.usda.gov/webdocs/publications/42805/51173 ap068.pdf

Lyson, M. C. (2014). The class politics of alternative food: Informing public health policy and remedying health inequality. Sociology C ompass, 8(10), 1216-1228. https://doi.org/10.1111/soc4.12202

Lyson, T. A. (2004). Civic agriculture: Reonnecting farm, food and ommunity. Medford, Massachusetts: Tufts University Press.

Lyson, T. A., \& Guptill, A. (2004). Commodity agriculture, civic agriculture and the future of U.S. farming. Rural Sociology, $69(3), 370-385$.

Monson, J., Mainville, D. Y., \& Kuminoff, N. V. (2008). The decision to direct market: An analysis of small fruit and specialty-product markets in Virginia. Journal of F ood D istribution Research, 39(2), 1-11. http://purl.umn.edu/55971

O’Hara, J. K., \& Low, S. A. (2016). The influence of metropolitan statistical areas on direct-to-consumer agricultural sales of local food in the Northeast. A griaultural and Resource E conomics R eview, 45(3), 539-562. https://doi.org/10.1017/age.2016.7 
Pfeffer, M. J., \& Lapping, M. B. (1995). Prospects for a sustainable agriculture on the Northeast's rural/urban fringe. In H. K. Schwarzweller \& T. A. Lyson (Eds.), Research in rural sociology and development: Sustainable agriaulture and rural communities, V ol.6 (pp. 67-93). Greenwich, Connecticut: JAI Press.

Ross, N. J. (2006). How civic is it? Success stories in locally focused agriculture in Maine. Renewable A grialture and F ood Systems, 21 (2), 114-123. https://doi.org/10.1079/RAF2005134

Selfa, T., \& Qazi, J. (2005). Place, taste, or face-to-face? Understanding producer-consumer networks in "local" food systems in Washington State. A griculture and H uman V alues, 22 (4), 451-464. https://doi.org/10.1007/s10460-005$\underline{3401-0}$

Smith, B. (2014, August 10). Don't let your children grow up to be farmers. N ew Y ork Times, p. SR5.

Stephenson, G., \& Lev, L. (2004). Common support for local agriculture in two contrasting Oregon communities. Renewable A griculture and F ood Systems, 19 (4), 210-217. https://doi.org/10.1079/RAFS200481

Stephenson, G., Lev, L., \& Brewer, L. (2008). 'I'm getting desperate': What we know about farmers' markets that fail. Renewable A griculture and F ood Systems, 23(3), 188-199. https://doi.org/10.1017/S1742170507002153

Stevenson, G. W, Clancy, K., King, R., Lev, L., Ostrom, M., \& Smith, S. (2011). Midscale food value chains: An introduction. Journal of A griaulture, Food Systems, and Community D evelopment, 1(4), 27-34. https://doi.org/10.5304/jafscd.2011.014.007

Thilmany, D., Bond, C. A., \& Bond, J. K. (2008). Going local: Exploring consumer behavior and motivations for direct food purchases. A merican Journal of A grialtural E onomics, 90(5), 1303-1309. https://doi.org/10.1111/i.1467$\underline{8276.2008 .01221 . x}$

Thomas, J. K., \& Howell, F. M. (2003). Metropolitan proximity and U.S. agricultural productivity, 1978-1997. Rural Sociology, 68(3), 366-386. https://doi.org/10.1111/j.1549-0831.2003.tb00142.x

Timmons, D., \& Wang, Q. (2010). Direct food sales in the United States: Evidence from state and county-level data. Journal of Sustainable A griculture, 34 (2), 229-240. https://doi.org/10.1080/10440040903482605

Uematsu, H., \& Mishra, A. K. (2011). Use of direct marketing strategies by farmers and their impact on farm business income. A griculture and Resource E conomics Review, 40 (1), 1-19. https://doi.org/10.1017/S1068280500004482

U.S. Department of Agriculture. (2012, August 3). U SD A D irectory records more than 7,800 farmers mark ets (Press Release No. 0262.12). Retrieved from https://www.usda.gov/media/press-releases/2012/08/03/usda-directory-recordsmore-7800-farmers-markets

U.S. Department of Agriculture, Economic Research Service [USDA ERS]. (2014). 2014 Farm household income forecast. Washington, D.C.: Author.

U.S. Department of Agriculture, National Agricultural Statistics Service [USDA NASS]. (2012). 2012 C ensus of agriaulture: Report form guide. Washington, DC: Author. Retrieved from http://www.agcensus.usda.gov/Help/Report Form and Instructions/2012 Report Form/2012 RFG Final.pdf

Vogel, S. \& Low, S. A. (2015, February 2). The size and scope of locally marketed food production. A mber W aves. Washington, D.C.: USDA, ERS. https://www.ers.usda.gov/amber-waves/2015/januaryfebruary/the-size-andscope-of-locally-marketed-food-production/ 